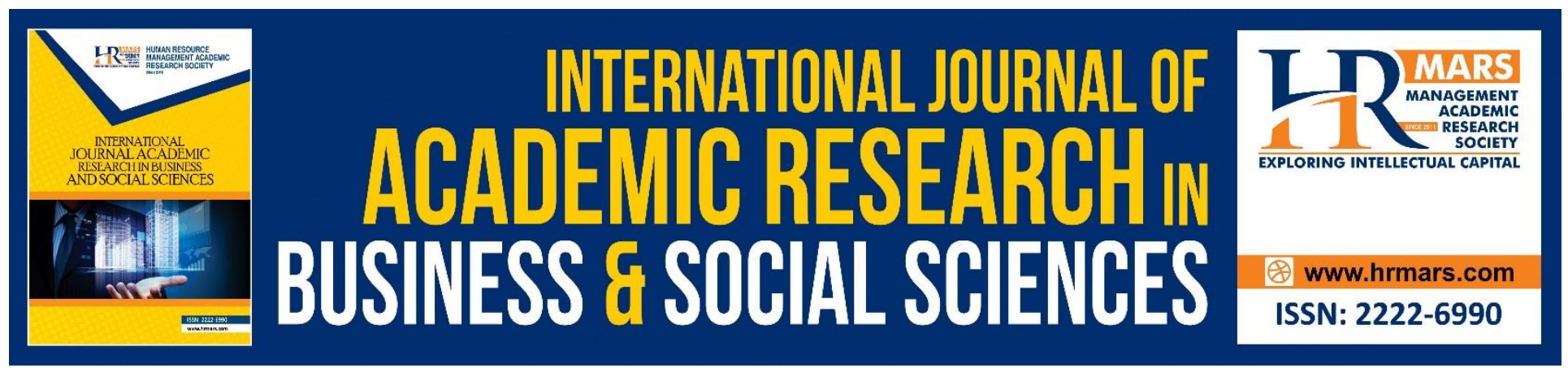

\title{
Negatives Impact Faced by Oil Palm Estate Management in managing Foreign Workers: A Case Study
}

Farahida Zulkefli, Syahrizan Syahlan and Mohd Firdaus Abdul Aziz

To Link this Article: http://dx.doi.org/10.6007/IJARBSS/v8-i9/4863

DOI: $\quad 10.6007 /$ IJARBSS/v8-i9/4863

Received: 03 August 2018, Revised: 25 August 2018, Accepted: 13 Sept 2018

Published Online: 15 Sept 2018

In-Text Citation: (Zulkefli, Syahlan, \& Aziz, 2018)

To Cite this Article: Zulkefli, F., Syahlan, S., \& Aziz, M. F. A. (2018). Negatives Impact Faced by Oil Palm Estate Management in managing Foreign Workers: A Case Study. International Journal of Academic Research in Business and Social Sciences, 8(9), 1525-1531.

Copyright: (C) 2018 The Author(s)

Published by Human Resource Management Academic Research Society (www.hrmars.com)

This article is published under the Creative Commons Attribution (CC BY 4.0) license. Anyone may reproduce, distribute, translate and create derivative works of this article (for both commercial and non-commercial purposes), subject to full attribution to the original publication and authors. The full terms of this license may be seen

at: http://creativecommons.org/licences/by/4.0/legalcode

Vol. 8, No. 9, September 2018, Pg. 1525 - 1531

http://hrmars.com/index.php/pages/detail/IJARBSS

JOURNAL HOMEPAGE

Full Terms \& Conditions of access and use can be found at http://hrmars.com/index.php/pages/detail/publication-ethics 


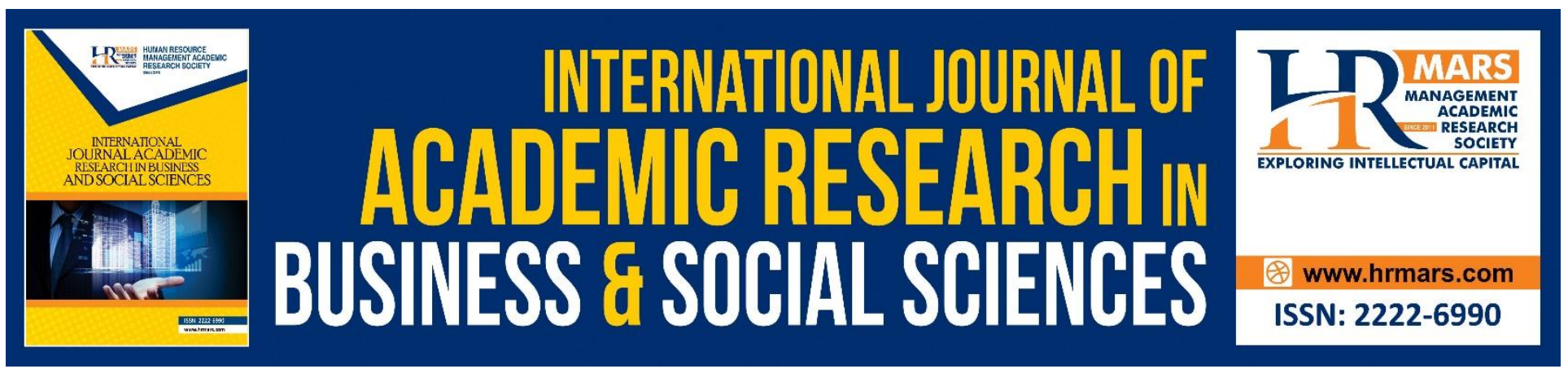

\title{
Negatives Impact Faced by Oil Palm Estate Management in managing Foreign Workers: A Case Study
}

\author{
Farahida Zulkefli, Syahrizan Syahlan and Mohd Firdaus Abdul Aziz \\ Faculty of Plantation and Agrotechnology Universiti Teknologi MARA (Melaka), Malaysia
}

\begin{abstract}
This paper investigates the negatives impact of foreign labour on oil palm estates through a case study of Kota Tinggi Johor, a state where foreign labour immigration has played a key role in palm oil growth over the past three decades. Data were collected through a structured interview and survey. The questionnaires were delegated to employer's representatives in Kota Tinggi Johor who have direct contacts with foreign workers. There were 97 sets of questionnaires completed and analyzed through the structured interviews. The main negative impacts induced by foreign workers are absenteeism, sexual harassment, alcoholism, discipline and criminal. Absenteeism and alcoholism factors showed significance difference towards estate management perspectives $(\mathrm{P}<0.05)$. This case study proves that there are still others factors influencing the negative impacts, social factors is not the only reason to affect. It must also being supported with economy and political factors in order to asses and control this challenges.
\end{abstract}

Keywords: Foreign Workers, Negatives Impact, Oil Palm Plantation, Estate Management and Perspectives.

\section{Introduction}

Local labour depletion problems experienced by Malaysia resulted in the country had to use foreign labour to fulfil the industries of the country. Malaysia is using the foreign labour as an asset of national development According to the Department of Statistics Malaysia 2010, there were 16\% registered foreign workers at plantation sectors in Malaysia. Wong and Anwar (2003) as cited by Hamzah Abdul-Rahman (2012), highlighted that Malaysia is one of the countries which has become the focus of foreign workers and it has the highest ratio of illegal foreign workers in its workforce.

Their presence has somewhat threatened the life of the local community who can bring many problems. Therefore, management of oil palm plantation should be confronted, deal, and make decisions with foreigners that have always pose problems and issues at workplaces especially in oil 
INTERNATIONAL JOURNAL OF ACADEMIC RESEARCH IN BUSINESS AND SOCIAL SCIENCES

Vol. 8, No. 9, Sept. 2018, E-ISSN: 2222-6990 @ 2018 HRMARS

palm plantation sector. However dependency of foreign worker in plantation sectors was the most highly demanded whether they have provided problem or issues for management.

Due to the increasing number of foreign worker year by year in oil palm plantation, management has received many problems and conflict regarding of them in the workplace. However, the problems faced by management regarding of managing foreign workers at workplace are numerous. In order to recognize and determine the issues, an empirical study has been conducted. The aim of this research study are: [1] To investigate the management's perception towards problems by foreign workers. [2] To identify the citizenship of foreign workers that contributed to the negatives impacts based on management's perspectives.

\section{Materials and Methods}

\section{Research framework}

Based on objectives and previous literature on this study, a research framework was developed. This research will provide further insight as to what extent can five variables influence the estate management perspectives.

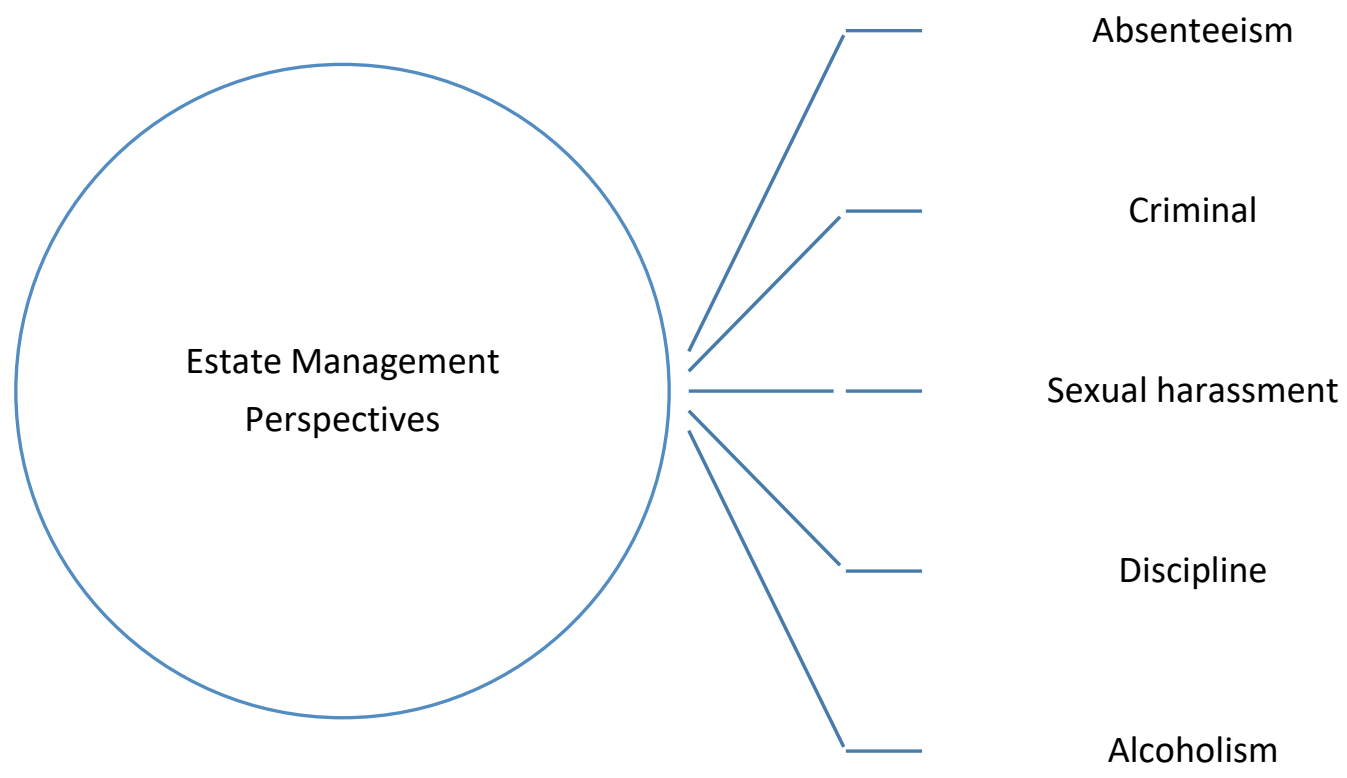

Figure 1: Negatives impact induced by foreign workers in management perspectives

\section{Data Collection}

Research study focused on oil palm plantation management that have been conducted surrounding area of Kota Tinggi Johor. The company A consists of 9 management with a total 0 19,000 ha. Area selected have stronger direct link between management of oil palm plantation with employment of foreign workers. The data have been collected based on management's perception towards problems 
by foreign workers in oil palm plantation. This research study involved data collection through questionnaires that was distributed to management workers who is register employed under Company A. Respondents that have answered the questionnaires be categorized into different of job position in management such as: [1] Senior Manager/manager [2] Assistant Manager [3] Field supervisor [4] Mandore.

\section{Results and Discussion}

\section{Reliability Test}

From table 1, the results of Cronbarch's alpha show a positive consistency on the data when Cronbach's Alpha value estimated was higher than the index of reliability test (0.6). This shows that there is consistency among the perspectives of estate management and it can be conclude that the study based on the questionaires is fit for this study.

Table 1: Result Reliability Test

\begin{tabular}{cc}
\hline Variables & Cronbach's alpha \\
& \\
\hline Absenteeism & 0.786 \\
Criminal & 0.856 \\
Sexual harassment & 0.792 \\
Discipline & 0.799 \\
Alcoholism & 0.843 \\
\hline
\end{tabular}

\section{Descriptive Analysis}

Table 2: Classification of problems by Mean Index (MI)

\begin{tabular}{llcc}
\hline Problem & MI & Class & Rank \\
\hline 1 Alcoholism & 3.62 & Agreed & 2 \\
2 Criminal & 3.47 & Slightly agreed & 4 \\
3 Sexual harassment & 3.11 & Slightly agreed & 5 \\
4 Absenteeism & 3.74 & Agreed & 1 \\
5 Discipline & 3.52 & Agreed & 3
\end{tabular}

The analysis of the data in Table 2 and showed the Mean Index (MI) and ranking of the negatives impact contributed by foreign workers in oil palm plantation surrounding Company A Kota Tinggi Johor based on management's perception. The highest selection problems that been agreed by most respondents of management were absenteeism (3.74 MI), alcoholism (3.62 $\mathrm{MI}$ ), and discipline (3.52 MI). The rest of problems were slightly agreed by the respondents such as criminal (3.47 MI) and sexual harassment (3.11 MI). 
Results based on second objective of this research study which is to identify the citizenship of foreign workers that contributed towards negatives impact based on management's perception. Table 3 showed the frequency, percentage, and ranking of the citizenship of foreign workers that contribute problems in oil palm plantation surrounding Company A Kota Tinggi based on management's perception. The findings showed that respondents were highly selected foreign workers from country of Indonesia (42.8\%), Bangladesh (25.8\%), Nepal (18.5\%), and India (12.9\%) as the citizenship of foreign workers that usually contribute problems to the management in oil palm plantation surrounding Company A Kota Tinggi based on their perception.

Table 3: Foreign workers by citizenship

\begin{tabular}{lccc}
\hline Citizenship & Frequency & Percent (\%) & Rank \\
\hline Bangladesh & 48 & 25.8 & 2 \\
India & 24 & 12.9 & 4 \\
Indonesia & 61 & 42.8 & 1 \\
Nepal & 30 & 18.5 & 3
\end{tabular}

\section{Relationship between Factors Contributed to Estate Management's Perspectives}

Pearson Correlation Analysis was used to identify the relationship between the independent variables (alcoholism, absenteeism, criminal, discipline and sexual harrasment) that affect the estate management perspectives.

Table 4: Significance Level between the Dependent Variable with the Independent Variables

\begin{tabular}{lcc}
\hline Independent Variable & $\mathrm{R}$ & $\begin{array}{c}\text { Dependent Variable } \\
\text { (Smallholder's behaviour) }\end{array}$ \\
\hline Alcoholism & & $p$ \\
Criminal & 0.261 & 0.046 \\
Absenteeism & -0.188 & 0.450 \\
Discipline & 0.386 & 0.003 \\
Sexual harassment & 0.057 & 0.666 \\
& 0.048 & 0.691
\end{tabular}

From table 4, we can see a significant value between the dependent variable and the independent variable. Based on table 4 , it is clearly seen that the absenteeism have a significant relationship because the value of significant, $p=0.003$ at $p<0.05$. Although there was a significant relationship between the two variables, but the relationship was weak because the $r$ - value was in the range of 0.20 until 0.39 , which categorized as weak. Thus, there was a significant weak positives relationship between the absenteeism and perspective. The second factor; alcoholism, have also a significant relationship because the value of significant, $p=0.046$ at $p<0.05$. Although there was a significant relationship between the two variables, but the relationship was weak because the $r$ - value was in 
INTERNATIONAL JOURNAL OF ACADEMIC RESEARCH IN BUSINESS AND SOCIAL SCIENCES

Vol. 8, No. 9, Sept. 2018, E-ISSN: 2222-6990 (C) 2018 HRMARS

the range of 0.20 until 0.39 , which categorized as weak. Thus, there was a significant weak positives relationship between the alcoholism and perception.

\section{Conclusion}

The results of this research study indicate that foreign workers usually provide and contribute problems to the management that influence to the negative impact to the organization and society. However, these findings are only acceptable and applicable for management of oil palm plantation surrounding Company A Kota Tinggi, Johor and cannot be generalized to outside of the organization. The same research study required to be conducted with management workers from other organizations or industries to seek if there are any similarities with the management's perception towards negatives impact induced by foreign workers in oil palm plantation. As suggestion based on findings and conclusions of the research study, the following are several recommendations to be considered such as management of oil palm plantation industry required in taking measurement of problems that provide and contribute by foreign workers that were employed. Secondly, the organisation should monitor foreign workers either in workplace or outside of workplace to ensure stability, sustainability, and security among society.

\section{Corresponding Author}

Farahida Zulkefli, Faculty of Plantation and Agrotechnology, Universiti Teknologi MARA (Melaka) Malaysia. Email: farahida@melaka.uitm.edu.my

\section{References}

Abubakar, S. Y. (2002). Migrant Labour in Malaysia: Impact and Implications of the Asian Financial Crisis. EADN Regional Project on the Social Impact of the Asian Financial Crisis.

Arif, M. M., Hamimah, A., Einur, B. H., Reza, E. M., \& Arzlee, H. A. (2012). Dependency of Foreign Workers in Malaysian Construction Industry. Built Environment Journal.

Azizi, Y., Noordin, Y., Talib, B. A., Sharifuddin, I., \& Chui, I. T. (2011). Stress Level and Its Influencing Factors among Employees in a Plastic Manufacturing and the Implication towards Work Performance. Elixir Psychology.

Carrie, H., Davidson, M., Fielden, S., \& Hoel, H. (2007). Sexual Harassment in the Workplace: A Literature Review. The Centre for Equality and Diversity at Work. Manchester Business School, University of Manchester.

Hamzah, A. R., Wang, C., Wood, L. C., \& Low, S. F. (2012). Negative Impact Induced by Foreign Workers: Evidence in Malaysian Construction Sector. Habitat International.

Lee, K. H., \& Sivananthiran, A. (1996). Contract Labour in Malaysia: Perspectives of Principal Employers, Contractors and Worker. International Labor Review. 
INTERNATIONAL JOURNAL OF ACADEMIC RESEARCH IN BUSINESS AND SOCIAL SCIENCES

Vol. 8, No. 9, Sept. 2018, E-ISSN: 2222-6990 (C) 2018 HRMARS

Department of Statistics. Principle Statistics of Labour Force. Malaysia, 2011.

Ministry of Human Resources. Immigration in Malaysia: Assessment of Its Economic Effects and A Review of The Policy and System. Human Development Social Protection and Labor Unit East Asia and Pacific Region, 2013.

Rahim, A. H., Bachan, S., Yusof, W. Z., Yusof, A. M., \& Mustafa, N. (2011). Problems Faced By Contractors in Managing Foreign Workers on Construction Sites. International Conference on Construction and Project Management.

Ramesh, K. (2012). The Impact of Employment of Foreign Workers: Local Employability and Trade Union Roles in Malaysia. International Journal of Academic Research in Business and Social Sciences.

Renuka, R., \& Basavanth, R. (2012). Employee Absenteeism: A Study at Titan Industry Limited, Banglore. The International Journal of Engineering and Science.

Soon, A., Van, D. L., \& Tomas, B. M. (2003). The Employment Relationships of Foreign Workers versus Local Employees: A Field Study of Organizational Justice, Job Satisfaction, Performance, and OCB. Journal of Organizational Behaviour.

Zulnasri, A. K. (2010). Palm Industry Labour: Issues, Performance and Sustainability. Government Policy on Foreign Labour. 